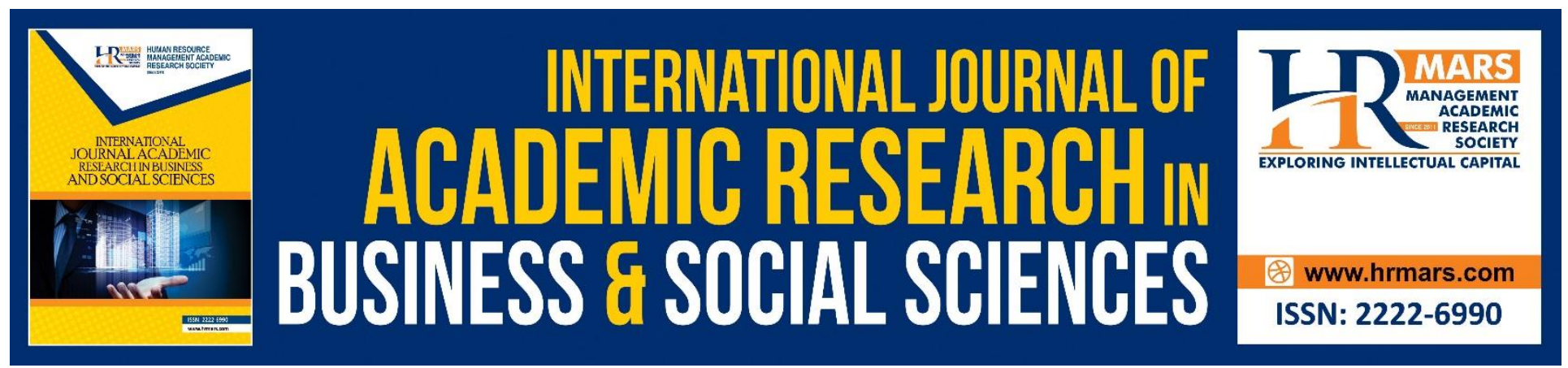

\title{
The Influence of Menu Description on Customer Purchase Intention
}

Shafinaz binti Ruhizat, Siti Norain binti Che Rahimi, Norzaidah binti Ngali, Norazlina binti Rahmat

To Link this Article: http://dx.doi.org/10.6007/IJARBSS/v11-i13/8552

DOI:10.6007/IJARBSS/v11-i13/8552

Received: 12 November 2020, Revised: 16 December 2020, Accepted: 29 December 2020

Published Online: 20 January 2021

In-Text Citation: (Ruhizat et al., 2021)

To Cite this Article: Ruhizat, S. binti, Rahimi, S. N. binti C., Ngali, N. binti, \& Rahmat, N. binti. (2021). The Influence of Menu Description on Customer Purchase Intention. International Journal of Academic Research in Business and Social Sciences, 11(13), 332-343.

Copyright: (C 2021 The Author(s)

Published by Human Resource Management Academic Research Society (www.hrmars.com)

This article is published under the Creative Commons Attribution (CC BY 4.0) license. Anyone may reproduce, distribute, translate and create derivative works of this article (for both commercial and non-commercial purposes), subject to full attribution to the original publication and authors. The full terms of this license may be seen

at: http://creativecommons.org/licences/by/4.0/legalcode

Special Issue: Beyond 2021 and COVID-19 - New Perspective in the Hospitality \& Tourism Industry, 2021, Pg. 332 - 343 http://hrmars.com/index.php/pages/detail/IJARBSS JOURNAL HOMEPAGE

Full Terms \& Conditions of access and use can be found at http://hrmars.com/index.php/pages/detail/publication-ethics 


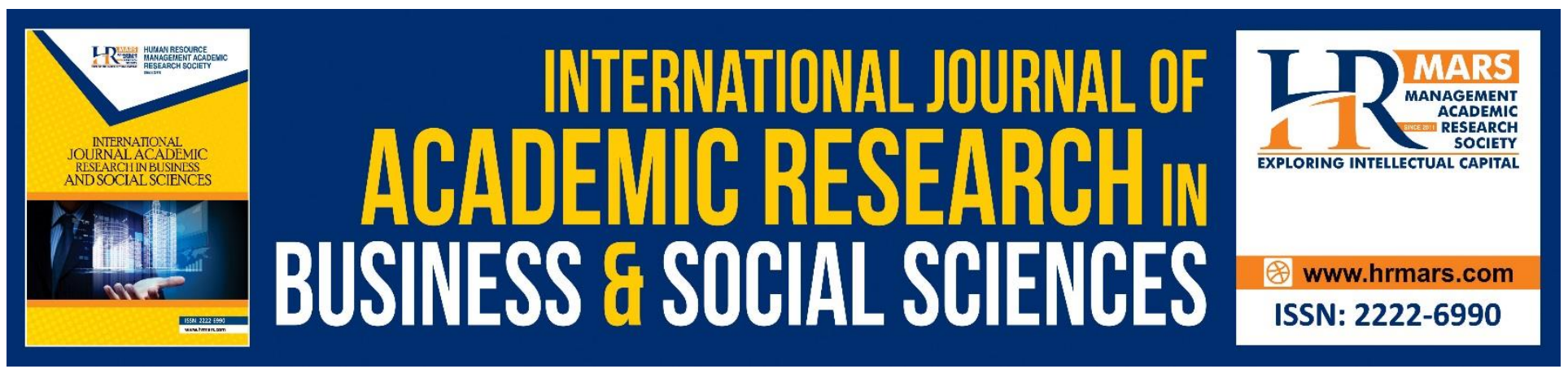

\title{
The Influence of Menu Description on Customer Purchase Intention
}

\author{
Shafinaz binti Ruhizat, Siti Norain binti Che Rahimi, Norzaidah binti \\ Ngali, Norazlina binti Rahmat
}

Faculty of Hotel and Tourism Management, Universiti Teknologi MARA Cawangan Terengganu Kampus Dungun, Terengganu, Malaysia

\begin{abstract}
Menu signifies the feature of food offers in restaurant; and each menu has its own description as it is a substantial marketing tool that may influence the customers' purchase intention and their experiences in enjoying the food offered. The purpose of this study is to investigate the factors in menu description that may influence customers' purchase intention. Next, it identifies the prominent factor that influences customer purchase intention. This study embraces four variables which are complexity of menu description, language used, nature of menu, and origin of menu. The study has adopted descriptive research design by using questionnaires survey for data collection. The convenience sampling method is used in this study and the targeted respondents are customers who had experienced dine in at Sri Molek Restaurant, Hotel UiTM Dungun. The result showed that the nature of menu is the prominent factor in menu description that influences the purchase intention. This indicates that the best menu description that emphasized on the nature of menu would influence customers' purchase intention. Therefore, the owner of restaurant should give more attention to nature of menu in the menu description during the process of menu planning and development. It is hope that this study will serve as significant support to academicians, service provider, and restaurant owners.
\end{abstract}

Keywords: Menu Description, Purchase Intention, Customer Behaviour, Customer and Menu.

\section{Introduction}

Menu description refers to providing relevant and sufficient information about menu items on the menu card (Ozdemir and Caliskan, 2015). Some people do not care about the information given on the menu card since they only want to spend their time enjoying the food or beverages at the best restaurant in order to acquire memorable experience. Fikri and Ramadhan (2011) stated that memorable dining experience is something that a service provider needs to focus on when providing services so that customers can remember it with good feeling. One of the factors that may affect the service is the menu description. Therefore, the service provider needs to provide clear and 
understandable menu description to the customers in order to deliver a good service. Menu can communicate to customers the promise of a unique experience and add value. In consequence, menu can be considered as a vital part of marketing strategy for the restaurant to promote the food and gaining more profits. A well description menu offered will give big impacts to market the food that needs to be sold. Indeed, a good and specific menu description plays an important role in the menu display.

Nonetheless, there are service providers who care less about menu writing as they always disregard in specifying menu description. As a result, it will have a bad impact not only to the waiter and waitress, but also to the customers. Misunderstandings will happen if the waiters give unclear or wrong descriptions of the food. Therefore, the customers will end up ordering foods that are familiar to them instead of ordering foods that are unfamiliar. The problem always happens on new menu if the description is vague. This study focuses on factors such as complexity of menu description, language used, nature of menu, and origin of food or ingredients (Elbadawy, Mohammed, and Jones, 2013). Finally, this study intends to identify the prominent factor in menu description that influences purchase intention.

\section{Literature Review}

\section{Complexity of Menu Description}

Elbadawy et al., (2013) stated that the level of complexity of a menu description may be classified from the absence of description beyond the name e.g. "Filet Mignon", through simple descriptions such as "10 oz grilled tenderloin, mushroom sauce and served with a choice of potato" to more complex descriptions for instance, "10 oz grilled tenderloin served with a sweet garlic and thyme crust, sliced vine ripe marinated tomato and smoked mozzarella cheese with a sherry vinegar demiglace". Unfortunately, the complexity of the menu description causes the problem as Davis, Lockwood, Alcott, and Pantelldis (2008) mentioned in their study that long descriptions require more spaces on menu card and also it may confuse the customers when they need to read long descriptions. However, Wansink, Painter, and Van Ittersum (2001) encountered this statement by explaining that customers will perceive the menu to be of higher quality and better value when the menu is described in. McCall and Lynn (2008) also supported this argument by stating that menu that are described in more complex terms might be seen as being higher in quality and more desirable than those items described in more basic terms. They recommended service providers to do so because increasing the descriptive complexity of menu could increase customers' intention to purchase the menu. Ozdemir and Caliskan (2015) agreed that the complexity of menu description able to enhance popularity of the menu as they found that the results after comparing the ratings of customers who placed order for menu with complex description higher than customers who chose menu with regular description.

Based on previous study on the complexity of menu description by McCall and Lynn (2008), the results showed that a more complex menu description increases the perception of quality of the food and the purchase intention of the customers. Specifically, when the menu is described in more complex way, customers will perceive the menu to be of high quality and that attracting them to purchase the menu. This is supported by Elbadawy et al., (2013) who mentioned that hotels that 
failed to use complex description for their menu will lose opportunities in the highly competitive marketplace.

\section{Language Used}

Imai, Kanero, and Masuda (2016) defined that language is a collection of narrative that reflect culture-specific value system and epistemologies. Language is the medium that people used to transfer the information about the cultures and values to others (Huffman and Davis, 2012). In the term of language in foodservice, language used to describe menu items that may create a good impression and induce customer orders (Elbadawy et al., 2013).

According to Paulson (2003), the language on the menu influences the customers' decision when ordering the food and beverages. Karasik (2003) mentioned that selling is like acting, where an actor's job is to approach and persuade a customer by evoking emotions. The customers will try to visualize or imagine the menu when they read the name of the menu (Hou, Yang, and Sun, 2017). Elbadawy et al., (2013) stated that some menus are written by using local language or by using the language, which is related to the cuisine such as Thai, Chinese, or Arabic. Also, the menus are presented with international language translation such as English, German, Italian, Japanese, and French. He added that the language used in the description of the menu may make the menu items sound interesting and can make the customers salivate hungry. Thus, the language used in the menu description is important to make the customers react positively to the menu because the language used in the menu description able to attract their intention.

Remar (2016) stated that the use of specific language to describe about the menu in the menu description may help the customers to make decision on what food that they wish to order. However, according to Thomas and Mills (2006), customers prefer variety of menus that are described in very simple language instead of flowery language as that may lead them into misunderstanding of the information during their decision-making. Moreover, Williams and Peter (2005) supported this finding as they found that increasing choices in the menu offered as compared to increasing the portion size is more important than the use of flowery language. Therefore, this study has been conducted in order to discover whether language will influence the purchase intention of customers.

\section{Nature of Menu Description}

Wansink et al., (2001) explained in their study about the menu description, which is based on sensory and affective description. Sensory description refers to the sense of taste, smell, and mouthfeel of menu items that are described from the names of food such as "Hearty Wholesome Steak", "Snappy Seasonal Carrots", and "Butter Plump Pasta". Tešanović, Banjac, Kalenjuk, and Radivojević (2016) stated that the menus with sensory characteristics are more appealing to customers as compared to regular menu description. Ozdemir and Caliskan (2015) mentioned that taste can be evaluated right after eating the food or drinking the beverages. Also, Lodorfos and Dennis (2008) stated that normally customers will try to predict or expect the taste that they will experience while they consume the food or beverages by relying on description of the menu. Meanwhile, Wansink, Van Ittersum and Painter (2005) claimed that customers will evaluate the taste 
of the food or beverages not only before consuming the food or beverage, but also after consuming them.

Affective description refers to adjective descriptive that promote emotional responses from the customers and reactivates pleasing memories (Wansink et al., 2001). For examples, "Classic Old Potato Bread" and "Nana's Favourite Chicken Soup". Affective description is related to ambiguous description. Ambiguous menu description refers to an unclear explanation of the menu. In most cases, ambiguous menu description stimulates the imagination more than a regular menu description (Hou et al., 2017). For example, when reading the regular descriptive name such as "Peach Tart with Almond Crust", consumers can easily visualize the food in their minds since the name is straightforward. This shows that customers understand easily the menu description. However, consumers may find it more difficult to visualize the menu because of the ambiguous description that might cause confusion and might make customers imagine irrelevant images of the dessert when reading the ambiguous menu description.

\section{The Origin of Food / Ingredients}

The origin of menu is the type of product information that is provided on the restaurant menu card (Mills and Thomas, 2008). Meanwhile, Simpson and Weiner (2000) elaborated the origin of menu involves the place of the food or something related to earliest known history. For example, Tasmanian Atlantic salmon that shows the origin of salmon is from Tasmanian Atlantic (Hartwell and Edwards, 2009). According to Thomas and Mills (2006), customers have concerns about the origin of foods and they desire to know the origin of foods on their menu card (Mills and Thomas, 2008). For instance, a customer might be concerned whether the vegetable offered on the menu card are fresh, frozen, canned, dried, or organic.

Food origin is important to customers as it can provide a quality guarantee and reduce the perceived risks (Hartwell and Edwards, 2009). This is supported by Apuli (2017) who stated that providing the origin of foods on the menu card able to improve customers' satisfaction. Unfortunately, the absence of this kind of menu description on menu card will lead customers towards dissatisfaction especially those who expect that information such as food origin will be provided on menu card at restaurant they eat (Bolton and Drew, 1991; Kangis and Passa, 1997). However, food origin may invoke positive or negative reaction depending on the food quality, the price, and also customers' perception towards the food origin in order to stimulate the purchase intention of the customers (Elbadawy et al., 2013).

\section{Customers' Purchase Intention}

Shah, Aziz, Jaffari, Waris, Ejaz, Fatima, and Sherazi, (2012) defined purchase intention as a type of decision-making by the customers who have reasons to buy a particular product. Based on previous study, Wansink et al., (2001) mentioned that menu description positively affect the purchase intention of the customers. This statement received support when they conducted a study with statistics that showed the percentage of customers who choose food that contain description in the menu is $27 \%$ higher than the customers who create food in the menu without a description. 
So, by preparing a menu description, customers are given a sense of responsibility as they already have the menus in their hand and have their own perception on the reviews of the menu, which influence the decision to order (Lockyer, 2006). It is important to write the menu description because it can attract the customers to purchase the food or beverages. Therefore, the researchers predicted that the variables of menu description such as complexity of menu description, language used, nature of menu description, and also origin of menu may give some sort of effects on purchase intention of the customers.

\section{Methodology \\ Research Design}

Descriptive research design was conducted for this study. A cross-sectional study was employed for data collection where focusing on statistical analysis of numerical data collected using the self-administrated questionnaires.

\section{Population and Sampling}

This study employed convenient sampling method as it is the most suitable way to collect data from the respondents. The respondents that involved in this study are the customers who had dined in at Sri Molek Restaurant, Hotel UiTM Dungun. This convenient sampling technique involved picking up any available set of respondents convenient for the researchers to use (Kumar, Abdul Talib and Ramayah, 2013). The sample for this study is based on the data obtained from sales manager of Sri Molek Restaurant, Hotel UiTM Dungun. The average customers who dined in at Sri Molek Restaurant 7 per day are 60 people. The process of data collection took only 7 days after receiving the permission given by the management of Hotel UiTM Dungun. So, the population for this study involved 420 customers for a week ( $p=420)$. In 7 days of data collection, total of 203 customers succeeded in answering questionnaires provided by the researchers. Therefore, 203 respondents $(n=201)$ were considered sufficient for this study (Krejcie and Morgan, 1970).

\section{Research Instruments and Data Collection}

Nominal scale was used for demographics that allowed the researchers to identify characteristic of respondents such as age, marital status, and educational background that might be influenced their opinion related with their dining experiences (Lavrakas, 2008). On the other hand, likert rated scale to measure behaviour items because it will specify a degree of agreement or disagreement with each of the question (Kumar et al., 2013). Odd number of categories for Likert scale was used as according to Kumar et al., (2013); this type of scale is generally used based on the experience judgement of the respondents.

This study employed questionnaires survey for data collection. Likert rated scale is used to measure behaviour items because it will specify a degree of agreement or disagreement with each of the questions (Kumar et al., 2013). Additionally, odd number of categories for Likert scale was employed since this type of scale is generally used based on the experience judgement of the respondents. 
INTERNATIONAL JOURNAL OF ACADEMIC RESEARCH IN BUSINESS AND SOCIAL SCIENCES

Vol. 11, No. 13, Beyond 2020 and COVID-19 - New Perspective in the Hospitality \& Tourism Industry. 2021, E-ISSN: 2222-6990 @ 2021 HRMARS

The questionnaires ask regarding on the factors that influence purchase intention in menu descriptions. The questionnaire for factors that influence purchase consists of the complexity of the menu descriptions, language used, nature of menu description, and origin of the food or ingredients. This section using rated scale, which means that the respondents have to choose options 1 for strongly disagree, 2 for disagree, 3 for neither agree nor disagree, 4 for agree, and 5 for strongly agree.

\section{Result and Analysis}

\section{The Demographic Profile of the Respondents}

From Table 1, 30\% of 203 respondents are male while $70 \%$ are female. The majority of respondents are 21 years old and below that gives the total of 126 respondents (63\%). Meanwhile, most of the respondents acquire college and university education levels and that gives the total of 177 respondents (87\%). In addition, most of the respondents are single (82\%), which equivalent to 167 respondents as compared to 36 respondents (18\%) who are married.

Table 1: Demographic Profile of the Respondents

\begin{tabular}{llcc}
\hline Classification & Type & Total $(\mathbf{n})$ & Percentage (\%) \\
\hline \multirow{2}{*}{ Gender } & Male & 60 & 30 \\
\cline { 2 - 4 } & Female & 143 & 70 \\
\hline \multirow{2}{*}{ Age } & 21 years old and below & 126 & 63 \\
\cline { 2 - 4 } & $22-29$ years old & 49 & 24 \\
\cline { 2 - 4 } & 30 years old and above & 27 & 13 \\
\hline \multirow{2}{*}{ Level of Education } & High School & 26 & 13 \\
\cline { 2 - 4 } & College/University & 177 & 87 \\
\hline \multirow{2}{*}{ Status } & Married & 167 & 82 \\
\cline { 2 - 4 } & Single & & 18 \\
\hline
\end{tabular}

The Factors in Menu Description that may Influence Customers' Purchase Intention

Complexity of menu description, language used, nature of menu description, and origin of food are the factors that have been investigated when looking at purchase intention.

Table 2: Factors in Menu Description that Influence Customer Purchase Intention ( $N=203)$

Dimensions Value (n) Percentage

(\%)

\begin{tabular}{|c|c|c|c|}
\hline \multicolumn{4}{|c|}{ Complexity of Menu Description } \\
\hline 1. Strongly Disagree & & 1 & 0.5 \\
\hline 2. Disagree & & 17 & 8 \\
\hline $\begin{array}{ll}\text { 3. } & \text { Neither Agree } \\
\text { Disagree } & \\
\end{array}$ & nor & 115 & 57 \\
\hline 4. Agree & & 67 & 33 \\
\hline 5. Strongly Agree & & 3 & 1.5 \\
\hline
\end{tabular}


INTERNATIONAL JOURNAL OF ACADEMIC RESEARCH IN BUSINESS AND SOCIAL SCIENCES

Vol. 11, No. 13, Beyond 2020 and COVID-19 - New Perspective in the Hospitality \& Tourism Industry. 2021, E-ISSN: 2222-6990 @ 2021 HRMARS

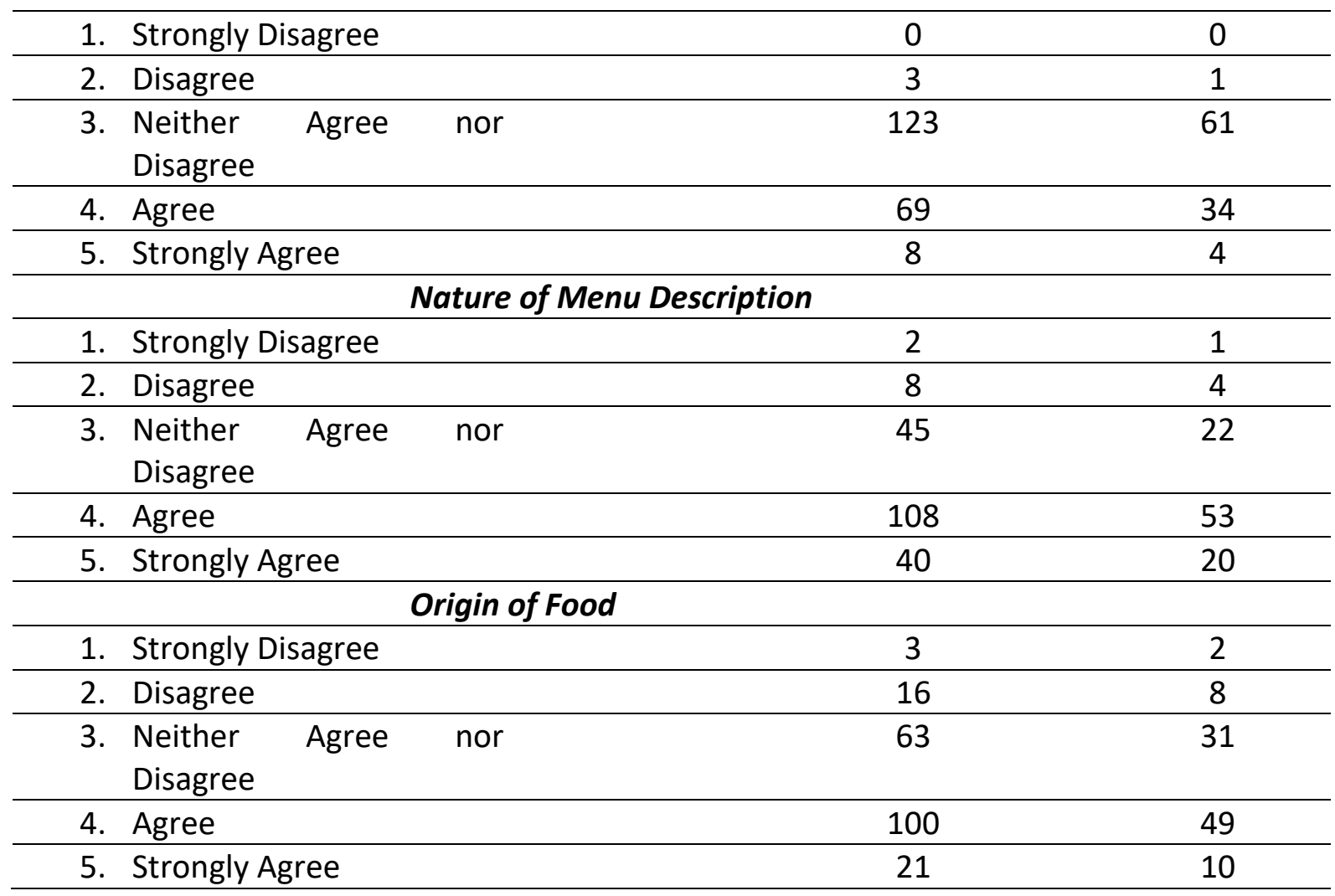

Table 2 shows that only 70 respondents (34.5\%) agreed and strongly agreed with the complexity of menu description that may influence customers' purchase intention. Mostly, providing information in description on menu card helped the customers to make their choices for the menu (Elbadawy et al., 2013), but the overload description may push the customers and would be ineffective in promoting menu to be purchased by the customers (Hwang and Lorenzen, 2008).

On the other hand, 77 respondents (38\%) agreed and strongly agreed for the language used in the menu description hence may influence their intention to purchase foods, while 123 respondents (60.6\%) are confused with the language so they marked the scale at safe zone, which is 3 at the Likert scale (neither agree nor disagree); and another 3 respondents (1.5\%) disagreed with the language as Sri Molek Restaurant used English language for their menu description. The researchers assumed that the customers who have lower educational level would prefer to have local language such as Malay language on the menu so that they would understand better about the menu offered. Meanwhile, the customers who have higher educational level might not have any trouble in understanding regardless whether it is in English or any other local languages such as Malay language.

However, the largest number of respondents which are 148 customers (73\%) have agreed and strongly agreed that nature of menu description has influenced them the most in purchasing the menu. Mostly, customers emphasized on the taste of the food that they eat at the restaurant (Tešanović et al., 2016). This finding is supported by Lockyer (2006) when he stated that the word 
used in menu description such as fresh, sweet, and salted helped the customers define the feeling for the menu and make the right decision to purchase the menu that they are interested.

Meanwhile, 121 respondents (59\%) have agreed and strongly agreed that origin of food in the menu description have also the role to influence customers to purchase foods. From that result, it shows that origin of menu can be considered as the factor that will influence customers purchase intention, but not so much as nature of menu description. According to Elbadawy et al., (2013), origin of menu may help the customers know where the menu item comes from or know the place of the menu item that has been obtained. This is supported by Senni Apuli (2017) when they said that the customers showed their interest towards origin of food that has been provided on menu card and it will improve the customers' experiences.

\section{The Prominent Factor in Menu Description that Influence Purchase Intention}

The prominent factor that influence purchase intention is the nature of menu description with calculated mean of 3.69. This followed by the origin of menu description with total mean of 3.39. The total mean for language used on menu description is 3.21. However, the least mean among the four variables is the complexity of menu description with only 3.15. All variables gained above 3.00 as it means score as reported in Table 3.

Table 3: The Prominent Factor in Menu Description that Influence Purchase Intention

\begin{tabular}{lcc}
\hline Variables & $\boldsymbol{n}$ & Mean \\
\hline $\begin{array}{l}\text { Language Used on Menu } \\
\text { Description }\end{array}$ & 203 & 3.21 \\
\hline Nature of Menu Description & 203 & 3.69 \\
\hline Complexity of Menu Description & 203 & 3.15 \\
\hline Origin of Food & 203 & 3.39 \\
\hline
\end{tabular}

Result of this study has confirmed that the prominent factor influencing the purchase intention based on menu description as highlighted by Telšanović, Banjac, Kalenjuk, and Radivojević (2016) that the menu with sensory characteristics has more influence on the customers as compared to regular menu description. Nature of menu description explains the sensory and affective description in menu description. Based on the researchers' observations, nature of menu truly affects the purchase intention because it describes how the food tastes like and helps customers to imagine the appearance of the food. This has been supported by Lodorfos and Dennis (2008) that normally customers will try to predict or expect the taste that they will experience when they consume the food or beverages by using the description of the menu. However, customers will evaluate the taste of food or beverages not only before consuming the food or beverage, but also after consuming them (Wansink et al., 2005).

Although customers who dined in at Sri Molek Restaurant understand the language used in the menu description, but there are some respondents confused with it. Therefore, the usage of clear, simple, and right language play an important role to construct the description of menu as to give the sensory and effective wording in menu description. As depicted from Stern (1988) a literary 
construct depends on words appealing to the senses and the sensory connection can bring a resourceful to the menu description. Also, the origin of food does not give a big influence on the customers purchase intention as much as the nature of menu description. This is because the customers focused more on the taste of the menu that allowing them to visualize the food or beverages. Moreover, providing information in description on menu card could help the customers to make their choices for the menu (Elbadawy et al., 2013), but the overload description may push the customers and would be ineffective in promoting menu to be purchased by the customers (Hwang and Lorenzen, 2008).

\section{Conclusion}

This study has reached the research objective to investigate and identify the prominent factor in menu description that may influence customers' purchase intention. Descriptive data analysis revealed that the factors such as complexity of menu, language used in menu description, nature of menu description, and origin of food may influence the purchase intention. Among all aforementioned factors, the prominent factor is the nature of menu description. Therefore, it is hope that this study may become guidelines for restaurants to create good and high-quality menu; and also improve their menu writing in order to influence the customers' purchase intention. Apart from that, the restaurants may increase their revenue when customers purchase the menu offered by the influential menu description. Last but not least, menu description is essential as one of the marketing tools and showing what the service provider can offer to their customers.

Future research may explore the reaction of customers' concerning the influential menu description to identify their acceptances. It is also recommended that a qualitative research to be conducted in order to reconfirm and acquire an in-depth result.

\section{Corresponding Author}

Norzaidah Ngali.

Universiti Teknologi MARA Cawangan Terengganu, Kampus Dungun, 23000 Dungun, Terengganu, Malaysia.

Email: norza319@uitm.edu.my

\section{References}

Bolton, R. N., \& Drew, J. H. (1991). A multistage model of customers' assessments of service quality and value. Journal of Consumer Expectation, 17(4), 375-384.

Davis, B., Lockwood A., Pantelidis, I., \& Alcott, P. (2008). Food and Beverage Management. $\left(4^{\text {th }}\right.$ ed), Butterworth-Heinemann, Oxford, UK.

Elbadawy, A., Mohammed, A., \& Jones, E. (2013). Menus as Marketing Tools: Developing a Resort Hotel Restaurant Menu Typology. Sci Technol. https://doi.org/10.4172/2324-8807.1000116

Fikri, M. K. R., \& Ramadhan, A. S. (2011). The effect of menu design on customer purchase intention: a case study of “WAROENG MAS KEMAL' RESTAURANT, 3(2), 137.

Hartwell, H., \& Edwards, J. (2009). Descriptive menus and branding in hospital foodservice: a pilot study. International Journal of Contemporary Hospitality Management. 21(7), 906-916. 
INTERNATIONAL JOURNAL OF ACADEMIC RESEARCH IN BUSINESS AND SOCIAL SCIENCES

Vol. 11, No. 13, Beyond 2020 and COVID-19 - New Perspective in the Hospitality \& Tourism Industry. 2021, E-ISSN: 2222-6990 @ 2021 HRMARS

Hou, Y., Yang, W., \& Sun, Y. (2017). Do pictures help? The effects of pictures and food names on menu evaluations. International Journal of Hospitality Management, 60, 94-103. https://doi.org/10.1016/j.ijhm.2016.10.008

Huffman, A., \& Davis, J. (2012). Language: communication and human behavior: The linguistic essays of William Diver. Boston: Brill.

Hwang, J., \& Lorenzen, C. L. (2008). Effective nutrition labeling of restaurant menu and pricing of healthy menu. Journal of Foodservice, 19, 270-276.

Imai, M., Kanero, J., \& Masuda, T. (2016). The relation between language, culture, and $\begin{array}{lllll}\text { though. Current } \quad \text { Opinion } & \text { in }\end{array}$ http;//doi.org/10.1016/j.copysyc.2015.10.001

Kangis, P., \& Passa, V. (1997). Awareness of service charges and its influence on cus- tomer expectations and perceptions of quality in banking. The Journal of Marketing Services, $11(2 / 3), 105-117$.

Karasik, P. (2003). What's your script? The words you use to sell can be very powerful. On Wall Street. New York: Nov 1, 1.

Krejcie, R. V., \& Morgan, D. W. (1970). Determining Sample Size for Research Activities. Educational and Psychological Measurement, 30, 607-610.

Kumar, M., Abdul Talib, S., \& Ramayah, T. (2013). Business Research Methods (p. 127,). Shah Alam: Oxford Fajar Sdn Bhd.

Lavrakas, P. J. (2008). Encyclopaedia of survey research methods. Thousand Oaks, CA: Sage

Publications, Inc. http;//doi.org/10.4135/9781412963947

Lodorfos, G. N., \& Dennis, J. (2008). Consumers' intent: In the organic food market. Journal of Food Products Marketing, 14(2), 17-38. http;//doi.org/10.1080/ 10454440801918218

Lockyer, T. (2006). Would a restaurant menu item by any other name taste as sweet? Hospitality review. 24(1), 21-31.

McCall, M., \& Lynn, A. (2008). The effects of restaurant menu item descriptions on perceptions of quality, Price, and purchase intention. Journal of Foodservice Business Research, 11(4), 439445. https://doi.org/10.1080/15378020802519850

Mills, J. E., \& Thomas, L. (2008). Assessing Customer Expectations of Information Provided On Restaurant Menus: A Confirmatory Factor Analysis Approach. Journal of Hospitality and Tourism Research, 32(1), 62-88. https://doi.org/10.1177/1096348007309569

Ozdemir, B., \& Caliskan, O. (2015). Menu Design: A Review of Literature. Journal of Foodservice Business Research, 189-206. https://doi.org/10.1080/15378020.2015.1051428

Paulson, D. (2003). Tag lines help create powerful images. Association Management, 55(13), 20.

Remar, D. A. (2016). The effects of environmental consciousness and menu information on consumers' perceptions of restaurant image and purchase behaviour related to local foods. Dissertation Abstracts International Section A: Humanities and Social Sciences, 77(1-A(E)), No Pagination Specified. https://doi.org/10.1002/fut153.

Shah, H., Aziz, A., Jaffari, A. R., Waris, S., Ejaz, W., Fatima, M., \& Sherazi, K. (2012), The Impact of Brands on Consumer Purchase Intentions. Asian Journal of Business Management, 4(2), 105-110.

Simpson, J. A., \& Weiner, E. S. C. (2000). The Oxford English Dictionary. University Press, Oxford: UK. 
Stern, B.B. (1988). How does an ad mean? Language in service advertising. Journal of advertising, I(712), 3-14.

Tešanović, D., Banjac, M., Kalenjuk, B., \& Radivojević, G. (2016). The impact of the names of dishes on the guest's choice of restaurant food. Proceedings of the Singidunum International Tourism Conference - Sitcon 2016, 169-173. https://doi.org/10.15308/Sitcon-2016-169-173

Thomas, L., \& Mills, J. E. (2006). Consumer knowledge and expectations of restaurant menus and their governing legislation: a qualitative assessment. Journal of Foodservice, 17(1), 6-22. https://doi.org/10.1111/j.1745-4506.2006.00015.x

Wansink, B., Painter, J., \& Van Ittersum, K. (2001). Do descriptive menu labels influence restaurant sales and repatronage? Cornell Hotel and Restaurant Administration Quarterly, 42, 68-72.

Wansink, B., Van Ittersum, K., \& Painter, J. E. (2005) How descriptive food names bias sensory perceptions in restaurants. Food Qual. Prefer, 16(5), 393-400.

Williams., P. \& Peter., W. (2005). Consumer Understanding and Use of Health Claims for Foods. Nutrition Reviews, 63, 256-65. 